\title{
METODE PEMBELAJARAN MIND MAP UNTUK MENINGKATKAN PRESTASI BELAJAR ANAK DIDIK SEKOLAH DASAR
}

\author{
Devi Setyarini \\ devisetyarini123@gmail.com \\ Fakultas Keguruan Ilmu Pendidikan Universitas Kristen Satya Wacana
}

\begin{abstract}
ABSTRAK
Rendahnya prestasi belajar anak Sekolah Dasar dapat dikarenakan oleh adanya beberapa gejala-gejala yang mampu mempengaruhi tingkat prestasi hasil belajar anak Sekolah Dasar. Salah satunya karena tidak berkonsentrasinya anak didik dalam mengikuti proses pembelajaran di sekolah. Dengan adanya fenomena tersebut, maka dilakukanlah beberapa penelitian untuk mengatasi fenomena tersebut dengan menggunakan metode Mind Map. Penelitian ini bertujuan untuk mengetahui keefektifan metode pembelajaran Mind Mapping terhadap aktivitas dan prestasi hasil belajar anak didik.
\end{abstract}

Kata kunci: Metode Mind Map, anak didik, prestasi hasil belajar, Sekolah Dasar

\section{PENDAHULUAN}

Pendidikan adalah pemegang peranan yang sangat dan sangatlah penting dalam guna untuk mempersiapkan dan memberikan ilmu tentang sumber daya manusia yang berkualitas dalam kehidupan sehari-hari, sehingga mampu mengahadapi apa yang menjadi sebuah tantangan di masa depan dan mampu untuk berlomba-lomba dalam berkompetisi pada dunia perkembangan ilmu pengetahuan dan teknologi informatika. Pendidikan merupakan sesuatu hal yang paling utama yang menjadi adanya tolak ukur perkembangan suatu bangsa agar tidak tertinggal dari bangsa lain. Sehingga, Sekolah Dasar merupakan sebuah tempat dalam mendapatkan sebuah pengalaman pertama yang dimana bisa memberikan dasar-dasar untuk pembentuk dari adanya kepribadian individu.

Dan selama ini, anak Sekolah Dasar hanya mendapatkan materi yang diberikan oleh guru dari pendidikan di sekolah. Nah, di sisi lain penguasaan cara belajar anak Sekolah Dasar dalam mengaplikasikan kejeniusan dan ketrampilan anak Sekolah Dasar kurang diperhatikan, seringnya terlupakan dan mirisnya tidak pernah didapatkan oleh anak didik selama dan semasa anak didik melakukan kegiatan atau aktivitas proses belajar di sekolah. Hal ini menyebabkan adanya ketidakseimbangan antar aspek bagaimana cara belajar dengan apa yang didapat dari belajar, akibatnya belajar bukanlah aktivitas atau kegiatan yang menyenangkan bagi anak didik. Hasilnya, anak didik tidak dapat untuk mengaplikasikan kemampuan, kreativitas, 
dan potensi terbaik otaknya dalam prestasi belajarnya.

Penguasaan sistem bagaimana cara belajar tidak akan dapat dimiliki ataupun dirasakan oleh anak didik semasa belajar di sekolah. Nah, metode pembelajaran Mind Map ini merupakan salah satu cara dalam mengatasi hal tersebut. Sebab, dengan menerapkan metode pembelajaran Mind Map merupakan salah satu sebuah sistem bagaimana cara belajar yang menyenangkan dan harus didapatkan paling awal oleh anak didik di Sekolah Dasar, apabila anak didik mau mengaplikasikan penggunaan otaknya secara efektif dan efisien dalam aktivitas atau kegiatan pembelajaran.

Penerapan metode pembelajaran Mind Map akan menuai sebuah prestasi hasil dari proses belajar anak didik Sekolah Dasar yang menyenangkan dan mendorong anak didik untuk lebih mandiri dalam belajar dan mencapai tingkat keberhasilan dalam prestasi akademiknya. Selain itu pula, penerapan metode pembelajaran Mind Map sudah mencangkup dari adanya karakteristik anak didik mulai dari kelas rendah hingga sampai anak didik pada kelas tinggi. Sehingga, penerapan metode pembelarajan Mind Map sangatlah memiliki pegaruh yang luar biasa sangat hebatnya dan positif bagi anak didik.
Dari adanya penguasaan sisi bagaimana cara belajar dan apa yang didapatkan dari belajar untuk anak didik mulai kelas rendah hingga adanya anak didik kelas tinggi sudah seimbang, efektif dan efisien, maka diharapkan untuk dengan anak didik dapat menyerap isi dan buah dari adanya materi pelajaran dan pengalaman belajar yang lebih baik pula, serta mampu menumbuhkembangkan atas adanya kecintaan oleh anak didik dalam mengikuti proses pembelajaran yang terdapat pada sekolah formal ataupun non-formal.

Adapun tujuan penelitian yang dapat dicantumkan dengan yang masih berkaitannya mengenai Metode Pembelajaran Mind Map untuk Meningkatkan Prestasi Hasil Belajar Anak Didik Sekolah Dasar. Berikut ini adalah tujuan penelitiannya:

1. Mengenali metode pembelajaran Mind Map.

2. Mengetahui hubungannya antara metode pembelajaran Mind Map dengan meningkatkan prestasi belajar anak didik Sekolah Dasar.

3. Memahami perlunya metode pembelajaran Mind Map diterapkan dalam proses pembelajaran di Sekolah Dasar.

4. Mengetahui cara menerapkan metode pembelajaran Mind Map di Sekolah Dasar. 
5. Mendapatkan hasil yang diperoleh dari penerapan metode pembelajaran Mind Map.

\section{METODE}

Penelitian ini berdasarkan dengan adanya studi dokumen yang diambil dari hasil-hasil penelitian yang sebelumnya sudah diterapkan dan teruji. Penelitian ini didasarkan dari jurnal-jurnal yang terdapat pada Google Cendekia. Dan dari hasil penelusuran tersebut dapat dipilah dan dipilihi, sehingga diperoleh 16 artikel dan 4 buku yang menyangkut dengan penelitian ini. Jadi penelitian ini menggunakan metode deskriptif untuk memahami, mengulas, dan menganalisi dari adanya jurnal-jurnal dan buku yang masih adanya keterkaitannya dengan penelitian ini tentang metode pembelajaran Mind Map untuk meningkatkan prestasi belajar anak didik.

Teori yang dapat diambil pada penelitian ini yakni dengan metode pembelajaran Mind Map ataupun peta pikiran merupakan sesuatu teknik grafis yang mampu untuk menyeimbangkan dengan adanya proses belajar di mana cara kerjanya yang masih alami berasalkan dari otak (Windura, 2008: 70). Metode pembelajaran Mind Map ini menggunakan semua dari prinsi-prinsip yang berhubungan dengan adanya manajemen otak manusia, terutama dalam kaitannya dengan menggunakan kedua belah otak kiri dan otak kanan baik itu secara aktif dan sinergis (Sutato Widura, 2008: 10). Dalam kegiatan penerapan pembelajaran yang berkaitannya dengan penggunaan metode pembelajaran Mind Map dengan tertunjuknya sebab dapat meningkatkan daya ingat dari otak dalam pembelajaran, akibatnya informasi yang disusun secara bercabang dari tema utama hingga cabangcabang yang mengikutsertakan beraneka macam gambar, simbol, warna dan bahan bacaan yang dapat menggali tentang anak didik untuk menggunakan seluruh potensi dan kapasitas otak yang secara efektif dan efisien (Dimas Qondias, DKK, 2016:3).

\section{HASIL DAN PEMBAHASAN}

Penelitian ini berdasarkan dengan adanya studi dokumen yang diambil dari hasil-hasil penelitian yang sebelumnya sudah diterapkan dan teruji. Atas dasar artikel jurnal-jurnal dan buku dari adanya hasil pencarian ataupun penelusuran yang sudah dipilih, dipilah dan ditelusuri menggunakan media Google Cendekia yang sudah terseleksi, maka hasil analisis terkait Metode Pembelajaran Mind Map untuk Meningkatkan Prestasi Belajar Anak Didik dapat diperiksa pada tabel yang ada di bawah ini. 
Tabel 1. Hasil Analisis Penelitian Terkait Metode Pembelajaran Mind Map untuk Meningkatkan Prestasi

Belajar Anak Didik

\begin{tabular}{|c|c|c|c|c|}
\hline No. & Peneliti & Judul/Tema & Tahun & Hasil \\
\hline 1. & $\begin{array}{l}\text { Eny } \\
\text { Sulistiyaningsih }\end{array}$ & $\begin{array}{l}\text { Peningkatan Kemampuan } \\
\text { Menulis Narasi dengan Metode } \\
\text { Peta Pikiran (Mind Mapping) } \\
\text { pada Siswa Kelas V SD Negeri } \\
\text { Karangasem III Surakarta Tahun } \\
\text { Pelajaran 2010/2011 }\end{array}$ & 2010 & $\begin{array}{l}\text { Metode peta pikiran (mind mapping) } \\
\text { dapat meningkatkan kemampuan } \\
\text { menulis narasi siswa. }\end{array}$ \\
\hline 2. & Al Amin Farij & \begin{tabular}{lr}
\multicolumn{3}{l}{ Peningkatan Pemahaman Sains } \\
Dengan Penggunaan Mind \\
Mapping Pada Siswa Kelas V \\
$\begin{array}{lr}\text { SD Negeri } & \text { Tirtomoyo } \\
\text { Kecamatan } & \text { Poncowarno } \\
\text { Kebumen Tahun } & \text { Pelajaran } \\
2010 / 2011 & \end{array}$
\end{tabular} & 2012 & $\begin{array}{l}\text { Melalui metode Mind Mapping dapat } \\
\text { meningkatkan pemahaman SAINS pada } \\
\text { siswa kelas V. }\end{array}$ \\
\hline 3. & $\begin{array}{l}\text { Annisa Aini, } \\
\text { Andayani, dan } \\
\text { Atikah Anindyarini }\end{array}$ & $\begin{array}{l}\text { Metode Mind Mapping } \\
\text { untuk Meningkatkan } \\
\text { Keterampilan Berbicara } \\
\text { Siswa Sekolah Dasar }\end{array}$ & 2012 & $\begin{array}{l}\text { Penggunaan metode mind mapping } \\
\text { dapat meningkatkan keaktifan } \\
\text { pembelajaran berbicara pada siswa, } \\
\text { dengan adanya peningkatan keaktifan } \\
\text { pembelajaran, maka hasil ketuntasan } \\
\text { belajar siswa pun mengalami } \\
\text { peningkatan. }\end{array}$ \\
\hline 4. & $\begin{array}{l}\text { Weni Arianingtyas } \\
\text { Uji Lestari, R. } \\
\text { Wakhid } \\
\text { Akhdinirwanto, } \\
\text { Arif Maftukhin }\end{array}$ & $\begin{array}{l}\text { Penggunaan Mind Mapping } \\
\text { untuk Meningkatkan Hasil } \\
\text { Belajar pada Siswa MTs Negeri } \\
\text { Purworejo }\end{array}$ & 2012 & $\begin{array}{l}\text { Penggunaan model pembelajaran Mind } \\
\text { Mapping dalam pembelajaran IPA } \\
\text { dapat meningkatkan aktivitas belajar } \\
\text { siswa sehingga hasil belajar siswa pun } \\
\text { meningkat, sebab siswa semakin senang } \\
\text { dan semangat untuk mempelajari IPA } \\
\text { dengan menggunakan model } \\
\text { pembelajaran Mind Mapping, akibatnya } \\
\text { hasil belajar siswa meningkat. }\end{array}$ \\
\hline 5. & Yusvidha Ernata & $\begin{array}{l}\text { Peningkatan Hasil Belajar IPS } \\
\text { melalui Model Mapping Materi } \\
\text { Sumber Daya Alam Kelas IV } \\
\text { SDN Ngaringan 05 Kecamatan } \\
\text { Gandusari Kabupaten Blintar }\end{array}$ & 2012 & $\begin{array}{l}\text { Pembelajaran mind mapping di sekolah } \\
\text { memberikan manfaat seperti } \\
\text { penyampaian materi pembelajaran di } \\
\text { sekolah menjadi mudah dan } \\
\text { meningkatnya keterampilan berfikir } \\
\text { siswa dalam memahami dan } \\
\text { menerapkan pembelajaran untuk } \\
\text { menyelesaikan permasalahan dalam } \\
\text { kehidupan sehari-hari. }\end{array}$ \\
\hline 6. & Chusnul Nurroeni & $\begin{array}{l}\text { Keefektifan Penggunaan Model } \\
\text { Mind Mapping } \\
\text { Terhadap Aktivitas dan Hasil } \\
\text { Belajar IPA }\end{array}$ & 2013 & $\begin{array}{l}\text { Model pembelajaran mind mapping } \\
\text { dapat meningkatkan aktivitas belajar } \\
\text { siswa. }\end{array}$ \\
\hline 7. & $\begin{array}{l}\text { David Yoga } \\
\text { Hardiyanto, } \\
\text { Suripto, Akhmad } \\
\text { Munib }\end{array}$ & $\begin{array}{l}\text { Penerapan Mind } \begin{array}{r}\text { Mapping } \\
\text { sebagai Media dalam }\end{array} \\
\text { Meningkatkan Kemampuan } \\
\text { Belajar IPA pada Siswa Kelas IV } \\
\text { SD Negeri } 1 \text { Sengare Kabupaten } \\
\text { Pekalongan }\end{array}$ & 2013 & $\begin{array}{l}\text { Penerapan Mind Mapping sebagai } \\
\text { media pembelajaran mampu } \\
\text { meningkatkan kemampuan belajar } \\
\text { secara signifikan, tidak hanya pada } \\
\text { pembelajaran penelitian ini namun juga } \\
\text { terhadap pembelajaran lain yang } \\
\text { menggunakan Mind Mapping sebagai } \\
\text { media pembelajaran. }\end{array}$ \\
\hline 8. & Yosi Purwasari & $\begin{array}{l}\text { Meningkatkan Hasil Belajar IPA } \\
\text { tentang Perubahan } \\
\text { Kenampakkan Permukaan Bumi } \\
\text { dan Benda Langit melalui Peta } \\
\text { Pikiran pada Anak Kesulitan }\end{array}$ & 2013 & $\begin{array}{l}\text { Adanya keberhasilan guru dalam } \\
\text { pembelajaran perubahan kenampakan } \\
\text { permukaan bumi dan benda langit } \\
\text { dengan membuat Peta Pikiran, } \\
\text { menjadikan Peta Pikiran dapat }\end{array}$ \\
\hline
\end{tabular}




\begin{tabular}{|c|c|c|c|c|}
\hline & & $\begin{array}{l}\text { Belajar Kelas IV SD } 13 \text { Balai- } \\
\text { Balai Kota Padang Panjang }\end{array}$ & & $\begin{array}{l}\text { memberikan efek yaitu dengan } \\
\text { meningkatnya hasil belajar siswa yang } \\
\text { mengalami kesulitan belajar kelas IV } \\
\text { SD. }\end{array}$ \\
\hline 9. & Sri Widianti & $\begin{array}{l}\text { Keefektifan Model } \quad \text { Mind } \\
\text { Mapping terhadap Hasil Belajar } \\
\text { IPS }\end{array}$ & 2014 & $\begin{array}{l}\text { Pengaruh model pembelajaran mind } \\
\text { mapping terhadap hasil belajar ditandai } \\
\text { dengan model pembelajaran mind } \\
\text { mapping lebih efektif untuk } \\
\text { meningkatkan hasil belajar siswa kelas } \\
\mathrm{V} \text { pada mata pelajaran IPS } \\
\text { dibandingkan model konvensional. }\end{array}$ \\
\hline 10. & $\begin{array}{l}\text { E. Kosmajadi dan } \\
\text { Neni Rohaeni }\end{array}$ & $\begin{array}{l}\text { Peningkatan Kemampuan } \\
\text { Menulis Puisi Bebas } \\
\text { dengan Menggunakan Teknik } \\
\text { Pemetaan Pikiran }\end{array}$ & 2015 & $\begin{array}{l}\text { Dengan menggunakan teknik pemetaan } \\
\text { pikiran sudah efektif, dan teknik } \\
\text { pemetaan pikiran dapat meningkatkan } \\
\text { kemampuan menulis puisi bagi siswa } \\
\text { kelas V SD, dan baik aktifitas siswa } \\
\text { selama proses pembelajaran maupun } \\
\text { hasil tes kemampuan menulis } \\
\text { menunjukkan peningkatan pada setiap } \\
\text { siklusnya. }\end{array}$ \\
\hline 11. & $\begin{array}{l}\text { Natriani Syam dan } \\
\text { Ramlah }\end{array}$ & $\begin{array}{l}\text { Penerapan Model Pembelajaran } \\
\text { Mind Mapping dalam } \\
\text { Meningkatkan Hasil Belajar } \\
\text { pada Mata Pelajaran Ilmu } \\
\text { Pengetahuan Sosial Siswa Kelas } \\
\text { IV SDN 54 Kota Parepare }\end{array}$ & 2015 & $\begin{array}{l}\text { Penerapkan model pembelajaran Mind } \\
\text { Mapping menunjukkan hasil yang } \\
\text { positif, karena dalam mind mapping } \\
\text { siswa selama pembelajaran diberikan } \\
\text { kesempatan berkomunikasi dengan } \\
\text { teman lainnya dalam } \\
\text { memecahkan masalah yang diberikan } \\
\text { dan dapat meningkatkan hasil belajar. }\end{array}$ \\
\hline 12. & $\begin{array}{lr}\text { Pt } & \text { Cahyani } \\
\text { Koriagung, I Kmg } \\
\text { Ngurah Wiyasa, } \\
\text { dan I.G.A. Agung } \\
\text { Sri Asri }\end{array}$ & $\begin{array}{l}\text { Penerapan Mind Mapping dalam } \\
\text { Pendekatan Saintifik untuk } \\
\text { Meningkatkan Hasil Belajar } \\
\text { PKN dan Pengetahuan Faktual } \\
\text { pada Tema Cita-Citaku Siswa } \\
\text { Kelas IVB SD Negeri 5 Tonja } \\
\end{array}$ & 2015 & $\begin{array}{lcr}\text { Penerapan mind mapping } & \text { dalam } \\
\text { pendekatan } & \text { saintifik } & \text { dapat } \\
\text { meningkatkan hasil belajar PKn. }\end{array}$ \\
\hline 13. & Dyah Safitri & $\begin{array}{l}\text { Penerapan Metode Mind } \\
\text { Mapping untuk Meningkatkan } \\
\text { Minat dan Hasil Belajar IPA } \\
\text { Siswa Kelas V SD N Balangan 1 }\end{array}$ & 2016 & $\begin{array}{l}\text { Penerapan metode mind map dapat } \\
\text { meningkatkan minat belajar dan hasil } \\
\text { belajar, sebab peningkatan minat dan } \\
\text { hasil belajar ditunjukkan dengan } \\
\text { meningkatnya nilai rata-rata } \\
\text { minat dan hasil belajar siswa. }\end{array}$ \\
\hline 14. & $\begin{array}{lr}\text { Dimas } & \text { Qondias, } \\
\text { Erna Laurensia } \\
\text { Anu, dan } & \text { Irama } \\
\text { Niftalia } & \end{array}$ & $\begin{array}{l}\text { Pengembangan Media Berbasis } \\
\text { Mind Mapping SD Kabupaten } \\
\text { Ngada Flores }\end{array}$ & 2016 & $\begin{array}{l}\text { Teknik mind mapping memberikan } \\
\text { kontribusi yang signifikan untuk belajar } \\
\text { siswa, terutama dalam bidang } \\
\text { pendidikan, karena mind maping dapat } \\
\text { meningkatkan kemampuan mengingat } \\
\text { yang berdampak pada hasil belajar } \\
\text { dengan rata-rata nilai dan presentase } \\
\text { ketuntasan klasikal yang diperoleh dan } \\
\text { media mind maping yang } \\
\text { dikembangkan telah sesuai dengan } \\
\text { kebutuhan para siswa SD. }\end{array}$ \\
\hline 15 . & $\begin{array}{l}\text { Muhammad Nur, } \\
\text { Eddy Noviana, } \\
\text { Syahrilfuddin }\end{array}$ & $\begin{array}{l}\text { Penerapan Model Pembelajaran } \\
\text { Kooperatif Tipe Mind Mapping } \\
\text { untuk Meningkatkan Hasil } \\
\text { Belajar PKn Siswa Kelas V SD } \\
\text { Negeri 59 Sebangar } \\
\text { Kecamatan Mandau }\end{array}$ & 2016 & $\begin{array}{l}\text { Penerapan Model Pembelajaran } \\
\text { Kooperatif Tipe Mind Mapping dapat } \\
\text { meningkatkan perkembangan kelompok } \\
\text { siswa karena siswa aktif untuk bekerja } \\
\text { sama dan saling membantu dalam } \\
\text { menyelesaikan tugas yang diberikan } \\
\text { pada kelompok masing-masing. }\end{array}$ \\
\hline
\end{tabular}




\begin{tabular}{|c|c|c|c|c|}
\hline 16. & Nur Astriany & $\begin{array}{l}\text { Meningkatkan Hasil Belajar IPA } \\
\text { Melalui Penggunaan Mind Map } \\
\text { Siswa Kelas IV Sekolah Dasar } \\
\text { Bekasi Utara }\end{array}$ & 2016 & $\begin{array}{l}\text { Dengan menggunakan Mind Map dapat } \\
\text { meningkatkan peranan siswa lebih aktif, } \\
\text { kreatif, dan inovatif dalam belajar dan } \\
\text { siswa merasa lebih senang dalam } \\
\text { pembelajaran sehingga pembelajaran } \\
\text { lebih bermakna. Hal tersebut dapat } \\
\text { terlihat pada peningkatan hasil belajar } \\
\text { siswa. Dan dalam pelaksanaannya guru } \\
\text { menggunakan Mind Map dalam bentuk } \\
\text { berfariasi dengan simbol dan warna } \\
\text { yang menarik sehingga dapat membuat } \\
\text { siswa lebih cepat menangkap materi } \\
\text { pembelajaran yang telah disampaikan. }\end{array}$ \\
\hline 17. & Femi Olivia & $\begin{array}{l}\text { Gembira Belajar dengan Mind } \\
\text { Mapping }\end{array}$ & 2008 & $\begin{array}{l}\text { Pengelompokkan materi semakin } \\
\text { menarik bila ditampilkan dalam wujud } \\
\text { visual. Mulai dari penggunaan gambar, } \\
\text { simbol, huruf, angka, hingga warna } \\
\text { beragam. Dengan visualisasi } \\
\text { pencatatan, dipastikan lebih } \\
\text { memudahkan untuk setiap orang } \\
\text { mengingat dan menyerap materi yang } \\
\text { dipelajari. Selain itu mind mapping } \\
\text { anak bisa memunculkan kreativitas } \\
\text { yang tidak pernah disadari olehnya, } \\
\text { bahwa sebenarnya ia telah memilikinya. } \\
\text { Karena mind mapping dapat } \\
\text { mensinergikan otak kiri dan kanan } \\
\text { dengan optimal. }\end{array}$ \\
\hline 18. & Tony Buzan & Buku Pintar Mind Map & 2008 & $\begin{array}{l}\text { Mind map merupakan suatu cara } \\
\text { mencatat yang kreatif, efektif, dan } \\
\text { secara harfiah akan memetakan pikiran- } \\
\text { pikiran. Di mana catatan tersebut dibuat } \\
\text { melalui adanya gagasan yang saling } \\
\text { berkaitan, dengan topik utama sebagai } \\
\text { inti yang dihubungkan dengan subtopik } \\
\text { dan cabang-cabangnya sebagai } \\
\text { perinciannya. }\end{array}$ \\
\hline 19. & Sutanto Windura & $\begin{array}{l}\text { Mind Map Langkah Demi } \\
\text { Langkah }\end{array}$ & 2008 & $\begin{array}{l}\text { Mind Map akan membantu anak } \\
\text { "menyusun kembali" materi pelajaran } \\
\text { atau permasalahan yang sedang } \\
\text { dihadapinya secara lebih sederhana dan } \\
\text { terstruktur sesuai pancaran pikirannya. } \\
\text { Dan Mind Map membuat anak lebih } \\
\text { memahami materi pelajarannya dan } \\
\text { proses belajar menjadi lebih } \\
\text { menyenangkan, karena melibatkan } \\
\text { kedua belah otak secara aktif. }\end{array}$ \\
\hline 20. & Caroline Edward & $\begin{array}{l}\text { Mind Mapping untuk Anak } \\
\text { Sehat dan Cerdas }\end{array}$ & 2009 & $\begin{array}{l}\text { Peta pikiran (mind mapping) } \\
\text { merupakan sebuah cara yang paling } \\
\text { efektif dan efisien untuk memasukkan, } \\
\text { menyimpan dan mengeluarkan data dari } \\
\text { atau ke otak, serta sistem terbaru yang } \\
\text { di desain sesuai dengan kerja alami otak } \\
\text { manusia. }\end{array}$ \\
\hline
\end{tabular}




\section{Metode pembelajaran Mind Map}

Secara garis besarnya saja, metode pembelajaran Mind Map ini merupakan sebuah bentuk dari adanya model pembelajaran yakni Discovery Learning. Kata "Mind Map" sendiri memiliki sebuah arti yakni suatu teknis grafis dimana yang memungkinkan dalam hal untuk adanya melakukan, mengeksplorasi dan mengaplikasikan seluruh dari kemampuan sebuah otak manusia untuk keperluannya dalam berfikir dan belajar.

Metode pembelajaran Mind Map adalah salah satu metode pembelajaran yang sistemnya menggunakan sebuah prinsip manajemen otak untuk membuka seluruh kreativitas, potensi, dan kapasitas otak yang masih tersembunyi. Metode pembelajaran Mind Map merupakan metode pembelajaran yang paling banyak manfaatnya. Kontribusinya dalam membantu anak didik dengan secara PAIKEM (Pembelajaran Aktif, Inovatif, Kreatif, Efektif, dan Menyenangkan) dan berfikir kritis.

\section{Hubungan antara metode pembelajaran} Mind Map dengan peningkatan prestasi belajar anak didik Sekolah Dasar

Penguasaan sistem bagaimana cara belajar tidak akan dapat dimiliki ataupun dirasakan oleh anak didik semasa belajar di Sekolah Dasar. Nah, metode pembelajaran
Mind Map ini merupakan salah satu cara dalam mengatasi hal tersebut. Sebab, dengan menerapkan metode pembelajaran Mind Map merupakan salah satu sebuah sistem bagaimana cara belajar yang menyenangkan dan harus didapatkan paling awal oleh anak didik, apabila anak didik mau mengaplikasikan penggunaan otaknya secara efektif dan efisien dalam aktivitas atau kegiatan pembelajaran.

Metode pembelajaran Mind Map yang akan dapat membantu anak dalam "menyusun kembali" materi pelajaran atau permasalahan yang sedang dihadapinya secara lebih sederhana dan terstruktur sesuai pancaran pikirannya. Penerapan metode pembelajaran Mind Map akan menuai sebuah prestasi hasil dari proses belajar anak didik Sekolah Didik yang menyenangkan dan mendorong anak didik Sekolah Dasar untuk lebih mandiri dalam belajar dan mencapai tingkat keberhasilan dalam prestasi akademiknya. Selain itu pula, penerapan metode pembelajaran Mind Map sudah mencangkup dari adanya karakteristik anak didik Sekolah Dasar mulai dari kelas rendah hingga sampai anak didik pada kelas tinggi. Sehingga, penerapan metode pembelajaran Mind Map sangatlah memiliki pegaruh yang luar biasa sangat hebatnya dan positif bagi anak didik Sekolah Dasar. 
Dari adanya penguasaan sisi bagaimana cara belajar dan apa yang didapatkan dari belajar untuk anak didik mulai kelas rendah hingga adanya anak didik kelas tinggi sudah seimbang, efektif dan efisien, maka diharapkan untuk dengan anak didik dapat menyerap isi dan buah dari adanya materi pelajaran dan pengalaman belajar yang lebih baik pula, serta mampu menumbuhkembangkan atas adanya kecintaan oleh anak didik dalam mengikuti proses pembelajaran.

\section{Perlunya metode pembelajaran Mind Map diterapkan dalam proses pembelajaran}

Mengapa pentingnya penerapan metode pembelajaran Mind Map terhadap pertumbuhan dan perkembangan anak Sekolah Dasar? Karena, metode pembelajaran Mind Map menerapkan prinsip kerja yang memilki daya tarik bagi anak Sekolah Dasar, sebab prinsip kerjanya menggunakan kedua belah otak anak Sekolah Dasar seperti tulisan, warna, dan gambar. Akibatnya mampu menarik perhatian anak Sekolah dasar untuk lebih berkonsentrasi dalam proses pembelajaran.

Keefektifan dari adanya metode pembelajaran mind mapping dalam meningkatkan hasil belajar anak didik tentu tidak terlepas dari berbagai kelebihan yang dimilikinya, seperti dalam membuat Mind Map ini anak didik Sekolah Dasar tidak hanya menggunakan otak kiri saja tetapi juga menggunakan belahan otak kanan yang bisa bermain dengan simbol, warna, dan gambar. Selain itu, Mind Map ini memberikan kebebasan kepada anak didik untuk menuangkan ide yang dimilikinya, kegiatan pembelajaran dengan metode pembelajaran Mind Map yang menyenangkan akan menimbulkan suasana positif dalam pembelajaran, dan Mind Map hanya mencatat hal-hal yang penting saja sehingga memudahkan anak didik mengingat dan mempelajari suatu hal dengan melihat hubungan yang terbentuk dari kata kunci, warna, dan gambar yang ada.

Gambaran dari Mind Map tidaklah rapi ketika ditulis, namun perlu dipahami bahwa apa yang kelihatannya rapi secara kasat mata belum tentu akan rapi menurut otak. Sebaliknya, gambar Mind Map yang terlihat kurang rapi tersebut malah yang lebih mudah dipahami dan disukai oleh otak. Sebab, Mind Map merupakan penyesuaian dengan cara kerja alami otak. Berikut contoh Mind Map tentang 4 Sehat 5 Sempurna. 


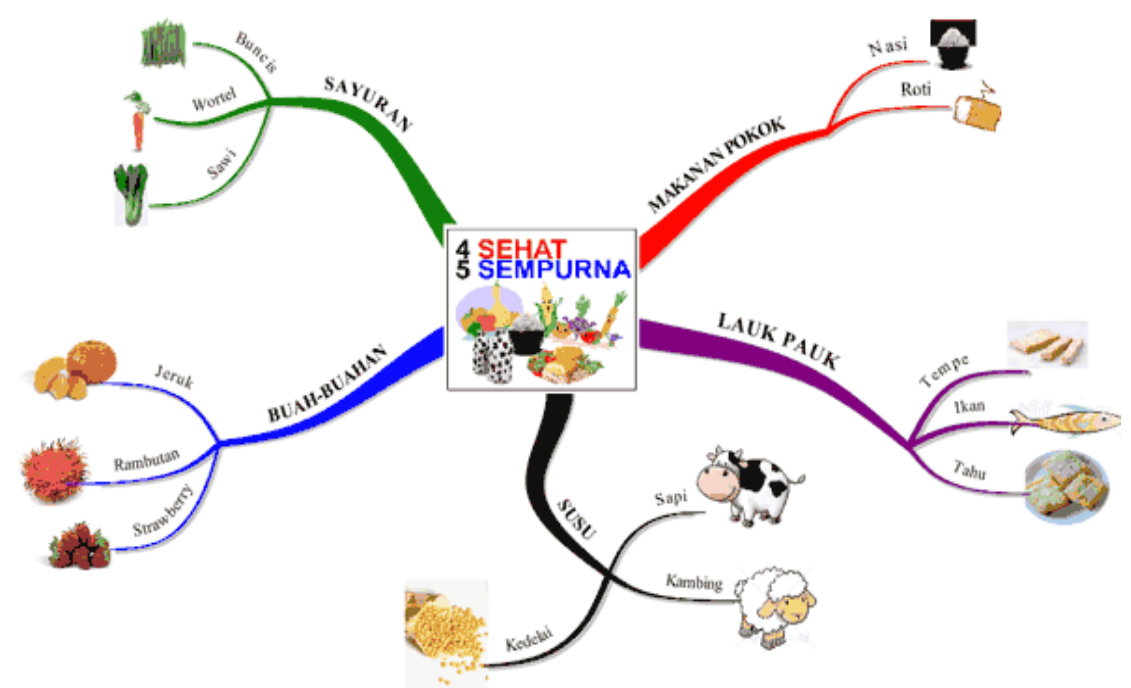

\section{Gambar 1. Contoh Mind Map tentang Makanan 4 Sehat 5 Sempurna}

Dari gambar contoh Mind Map di atas, maka terlihatlah kelebihan dari menggunakan model pembelajaran Mind Map yaitu unsur otak kiri dan otak kanan yang dapat terlibat sekaligus dan bersamasama.

\section{Tabel 2. Penggolongan Unsur Otak Kanan dan Kiri}

\begin{tabular}{|l|l|}
\hline \multicolumn{1}{|c|}{ OTAK KIRI } & OTAK KANAN \\
\hline Tulisan & Warna \\
\hline $\begin{array}{l}\text { Urutan } \\
\text { Penulisan }\end{array}$ & Gambar \\
\hline $\begin{array}{l}\text { Hubungan } \\
\text { antarkata }\end{array}$ & $\begin{array}{l}\text { Dimensi (tata } \\
\text { ruang) }\end{array}$ \\
\hline
\end{tabular}

Dari gambaran otak kiri dan otak kanan pada tabel di atas, maka nampak dengan jelas bahwa Mind Map melibatkan secara aktif kedua belah otak, yakni otak kiri dan otak kanan. Dengan demikan, Mind Map dapat mengatasi semua permasalahan belajar anak didik yang bersumber dari tidak adanya penggunaan kedua belah otak secara sinergis atau singkron.

\section{Cara menerapkan metode pembelajaran Mind Map di Sekolah Dasar}

Sebelum menginjak ke penerapan metode pembelajaran Mind Map di Sekolah Dasar, ada baiknya terlebih dahulu mengenal apa saja yang termasuk bahan dalam membuat metode pembelajaran Mind Map, ketentuan-ketentuan dalam membuat metode pembelajaran Mind Map dan langkah-langkah membuat Mind Map. Di bawah ini terdapat pernyataan yang mengenai ulasan-ulasan tersebut.

1. Bahan dalam membuat metode pembelajaran Mind Map menurut Sutanto Windura (2008:33), yaitu: 
a. Kertas putih polos (tidak bergarisgaris) dengan ukuran minimal A4 $(21 \times 29,7 \mathrm{~cm})$.

b. Pensil warna atau spidol, minimal 3 warna, dan bervariasi seperti ada yang tebal dan ada juga yang tipis.

c. Imajinasi.

d. Otak.

2. Ketentuan-ketentuan dalam membuat metode pembelajaran Mind Map menurut Sutanto Windura (2008:3435), yaitu:

a. Kertas

1) Posisi kertas mendatar (landscape).

2) Posisi tetap (steady).

b. Pusat Mind Map

1) Merupakan ide atau gagasan utama, biasanya merupakan judul bab suatu pelajaran atau permasalahan pokoknya.

2) Dalam meringkas atau mengkaji ulang, biasanya adalah judul bab atau tema pokok.

3) Haruslah berwujud gambar yang disertai dengan tulisan.

4) Terletak di tengah-tengah.

c. Cabang Utama

1) Sering disebut dengan $\mathrm{BOI}$ (Basic Ordering Ideas), yang merupakan cabang tingkat pertama yang langsung memancar dari Pusat Peta Pikiran.

2) Untuk keperluan meringkas biasanya merupakan subbabsubbab dari materi pelajaran yang dipelajari oleh anak didik.

3) Setiap cabang utama yang berbeda sebaiknya menggunakan warna pensil atau spidol yang berbeda pula.

d. Cabang

1) Diusahakan meliuk, bahkan sekadar melengkung atau lurus.

2) Pangkal tebal lalu menipis.

3) Semakin jauh dari Pusat Mind Map, maka semakin tipis.

4) Panjangnya sesuai dengan panjang kata kunci atau gambar di bagian atasnya.

5) Bercabang ke segala arah.

e. Kata

1) Berupa satu kata kunci (keyword).

2) Kata dituliskan di bagian atas cabang.

3) Semakin keluar, maka semakin kecil ukuran hurufnya. 
4) Tulisan tegak, maksimal kemiringannya yaitu 45 derajat.

f. Gambar

1) Sebanyak mungkin.

2) Berkaitan dengan materi pembelajaran yang merupakan sebuah ringkasan dari kata kunci.

3) Menarik

4) Warna

5) Berwana-warni.

6) Nampak "HIDUP".

g. Tata Ruang

1) Sesuai dengan besarnya ukuran kertas.

2) Terlihat penuh dengan cabang, kata, maupun gambar,serta warna-warna yang menghiasi.

3. Langkah-langkah membuat metode pembelajaran Mind Map menurut Sutanto Windura (2008:35-40), yaitu:

a. Sediakan selembar kertas ukuran A4 (ukuran folio atau A3 juga boleh) yang polos (tidak bergarisgaris), dan letakkan dalam posisi yang mendatar (landscape).

b. Buatlah Pusat Mind Map atau yang biasa disebut dengan Central Image, sebab harus diusahakan berupa gambar. Dan gambarkanlah pada bagian tengah- tengah kertas tersebut. Selain gambar dituliskan pula tulisan atau judul besar Mind Map yang ingin dibuat, namun perlu diperhatikan yaitu antara gambar dengan tulisan haruslah ada ketersambungannya.

c. Selanjutnya, buatlah cabang utama beserta kata untuk mengisi cabang utama. Setelah usai membuat cabang utama lalu dari cabang utama dilanjutkan dengan meneruskan cabang utama menjadi beberapa cabang sesuai dengan kata kunci yang ingin dibuat.

d. Setelah selesai membuat cabang utama beserta cabang-cabangnya, lalu dapat membuat cabang utama yang kedua, ketiga, keempat dan seterusnya yang lengkap beserta cabang-cabangnya.

e. Setiap cabang memiliki warna yang berbeda dari mulain cabang utama ke cabang kedua, ketiga, keempat dan lainnya. Namun, dari satu cabang utama hingga anak cabangnya harus satu warna.

Penerapan metode pembelajaran Mind Map dapat diterapkan dalam kegiatan pembelajaran di Sekolah Dasar yakni pada bagian inti dalam pengemasannya yang perlu diperhatikan guna menuangkan ide 
atau gagasan dari anak didik Sekolah Dasar yaitu mencari informasi dengan kata kunci, mengumpulkan data dengan mencabangkan dengan cabang-cabang yang berisi materi, menganalisa data, mengevaluasi data, dan menyajikan data dengan tulisan, gambar, simbol, angkat, huruf, dan beraneka macam warna yang dapat dengan mudah memahami materi yang ditangkap, dikembangkan, dan ditransfer oleh anak didik melaui metode pembelajaran Mind Map.

\section{Hasil yang Diperoleh dari Penerapan Metode Pembelajaran Mind Map}

Nah, hasil yang dapat diperoleh dari adanya penerapan metode pembelajaran Mind Map seperti yang sudah diuraikan dalam penelitian-penelitian sebelumnya dan beberapa buku penunjang metode pembelajaran Mind Map memiliki tingkat positif. Di mana tingkat positif ataupun tingkat yang baik dalam aspek pemahaman suatu konsep dan materi yang dituangkan ke dalam bentuk gambar, tulisan, warna, simbol, ataupun tanda yang mengapresiasikan adanya gagasan ke kertas yang putih.

Sedangkan, gagasan yang dapat diambil dari penulis yaitu tentang hasil yang diperoleh dari penerapan metode Mind Map ini sangat berkualitas dalam mengembangkan potensi dan ketrampilan siswa ataupun anak didik dalam mengidentifikasikan suatu permasalahan, mengapresiasikan dengan sejuta warna, segala rupa gambar, cabang materi, dan menyajikan gagasan atau idenya dengan secantik mungkin semenariknya. Perolehan dari adanya penerapan metode pembelajaran Mind Map begitu efektif dan efisien, sehingga mampu memberikan daya tarik dari siswa untuk fokus dalam proses pembelajaran yang sedang berlangsung. Selain itu, hasil prestasi belajar yang diraih atau dicapai oleh siswa mengalami peningkatan yang signifikan dalam pemahaman dari materi melalui konsep metode pembelajaran Mind Map. Mulai dari pendidik atau guru di Sekolah Dasar yang menerapkan metode pembelajaran Mind Map ini mengalami hasil yang baik serta kemudahan dalam mentransfer materi kepada siswa. Dan, untuk siswa yang mendapatkan penerapan metode pembelajaran Mind Map mengalami tingkat kefokusan yang tinggi terhadap pembelajaran dan prestasi belajar siswa pun mengalami kemajuan atau peningkatan yang baik.

\section{SIMPULAN}

Dapat ditarik kesimpulannya dari uaraian di atas mengenai Metode Pembelajaran Mind Map untuk Meningkatkan Prestasi Hasil Belajar Anak 
Didik, bahwa metode pembelajaran Mind Map merupakan sebuah bentuk dari model pembelajaran Discovery Learning. Kata "Mind Map" sendiri memiliki arti yakni suatu teknis grafis yang memungkinkan dalam mengeksplorasi dan mengaplikasikan seluruh kemampuan otak untuk keperluan berfikir dan belajar.

Pentingnya penerapan metode pembelajaran Mind Map terhadap pertumbuhan dan perkembangan anak didik Sekolah Dasar, disebabkan oleh prinsip kerjanya menggunakan kedua belah otak anak didik seperti tulisan, warna, dan gambar. Sehingga, dapat membuat anak didik Sekolah dasar berkonsentrasi saat waktu proses pembelajaran yang berlangsung dan dapat meningkatkan prestasi hasil belajar anak didik Sekolah Dasar. Dari adanya penguasaan sisi bagaimana cara belajar dan apa yang didapatkan dari belajar untuk anak didik Sekolah Dasar mulai kelas rendah hingga adanya anak didik kelas tinggi sudah seimbang, efektif dan efisien.

Penerapan metode pembelajaran Mind Map dapat diterapkan dalam kegiatan pembelajaran di Sekolah Dasar pada bagian inti dalam pengemasannya yang menyenangkan. Perolehan dari adanya penerapan metode pembelajaran Mind Map begitu efektif dan efisien, sehingga mampu memberikan daya tarik dari siswa untuk fokus dalam proses pembelajaran yang sedang berlangsung.

Berdasarkan hasil dan pembahasan penelitian yang sudah di atas tadi, dapat diberikankan saran-saran untuk dapat dikembangkan dan ditindaklanjuti dalam selanjutnya yakni metode pembelajaran Mind Map untuk meningkatkan prestasi belajar anak didik Sekolah Dasar sangat bermanfaat bagi pembelajaran yang terdapat di Sekolah Dasar terlebih pengembangan ini dapat dilakukan di khalayak yang lebih sangat dan sangat luas lagi. Guru Sekolah Dasar hendaknya lebih cermat dan teliti dalam memilih dan memilah metode dan strategi pembelajaran supaya proses belajar-mengajar di kelas dapat berlangsung secara efektif dan efisen. Sehingga memudahkan para guru ataupun pendidik Sekolah dasar di luar sana untuk melaksanakan pembelajaran yang menyenangkan, efektif, efisien, kreatif, inovati dan menciptakan pemikiran kritis dari siswa atau anak didik Sekolah Dasar.

\section{DAFTAR PUSTAKA}

Annisa, dkk. (2012). Metode Mind Mapping untuk Meningkatkan Keterampilan Berbicara Siswa Sekolah Dasar. Journal of Drug Issues, Vol. 1 (1), I2302-6405.

Astriany, N. (2016). Meningkatkan Hasil Belajar IPA Melalui Penggunaan Mind Map Siswa Kelas IV Sekolah 
Dasar Bekasi Utara. Journal of Drug Issues, Vol. 6 (1).

Buzan, T. (2008). Buku Pintar Mind Map. Jakarta: Gramedia.

Ernata, Y. (2012). Peningkatan Hasil Belajar IPS melalui Model Mapping Materi Sumber Daya Alam Kelas IV SDN Ngaringan 05 Kecamatan Gandusari Kabupaten Blintar.

Edward, C. 2009. Mind Mapping untuk anak sehat dan cerdas. Sakti: Yogyakarta.

Farij, Al Amin. 2012. Peningkatan Pemahaman Sains Dengan Penggunaan Mind Mapping Pada Siswa Kelas V SD Negeri Tirtomoyo Kecamatan Poncowarno Kebumen Tahun Pelajaran 2010/2011. Skripsi, tidak diterbitkan. Universitas Muhammadiyah Purworejo, Purworejo.

Hardiyanto, David Yoga, dkk. (20123). Penerapan Mind Mapping sebagai Media dalam Meningkatkan Kemampuan Belajar IPA pada Siswa Kelas IV SD Negeri 1 Sengare Kabupaten Pekalongan. Journal of Drug Issues, 1, 2252-6447.

Koriagung, Cahyani, Pt., dkk. (2015). Penerapan Mind Mapping dalam Pendekatan Saintifik untuk Meningkatkan Hasil Belajar PKN dan Pengetahuan Faktual pada Tema Cita-Citaku Siswa Kelas IVB SD Negeri 5 Tonja. Journal of Drug Issues, Vol.3 (1).

Kosmajadi, E. dan Neni Rohaeni. (2015). Peningkatan Kemampuan Menulis Puisi Bebas dengan Menggunakan Teknik Pemetaan Pikiran. Journal of Drug Issues, Vol.1 (1), 2442-7470.
Lestari, Weni Arianingtyas Uji, dkk. (2012). Penggunaan Mind Mapping untuk Meningkatkan Hasil Belajar pada Siswa MTs Negeri Purworejo. Journal of Drug Issues, Vol.1 (1).

Nurroeni, Chusnul. (2013). Keefektifan Penggunaan Model Mind Mappingterhadap Aktifitas dan Hasil Belajar IPA. Journal of Drug Issues, Vol.1, 2252-9047.

Nur, Muhammad, dkk. (2016). Penerapan Model Pembelajaran Kooperatif Tipe Mind Mapping untuk Meningkatkan Hasil Belajar PKn Siswa Kelas V SD Negeri 59 Sebangar Kecamatan Mandau. Jurnal Online Mahasiswa, Vol.4 (1).

Olivia, Femi. 2008. Gembira Belajar dengan Mind Mapping. Jakarta: Gramedia.

Purwasari, Yosi. (2013). Meningkatkan Hasil Belajar IPA tentang Perubahan Kenampakkan Permukaan Bumi dan Benda Langit melalui Peta Pikiran pada Anak Kesulitan Belajar Kelas IV SD 13 Balai-Balai Kota Padang Panjang. Jounal of Drug Issue, Volume 1 Nomor 1.

Qondias, Dimas, dkk. (2016). Pengembangan Media Berbasis Mind Mapping SD Kabupaten Ngada Flores. Journal of Drug Issues, 2, 2303-288X.

Safitri, Dyah. (2016). Penerapan Metode Mind Mapping untuk Meningkatkan Minat dan Hasil Belajar IPA Siswa Kelas V SD N Balangan 1. Journal ofDrugs Issues, Jurnal Pendidikan Guru Sekolah Dasar Edisi 3 Tahun ke-5.

Sulistiyaningsih, Eny. (2010). Peningkatan Kemampuan Menulis Narasi dengan 
Metode Peta Pikiran (Mind Mapping) pada Siswa Kelas V SD Negeri Karangasem III Surakarta Tahun Pelajaran 2010/2011.

Syam, Natriani dan Ramlah. (2015). Penerapan Model Pembelajaran Mind Mapping dalam Meningkatkan Hasil Belajar pada Mata Pelajaran Ilmu Pengetahuan Sosial Siswa Kelas IV SDN 54 Kota Parepare. Journal of Drug Issues, Vol.5 (3), 2088-2092.
Widianti, Sri. (2014). Keefektifan Model Mind Mapping terhadap Hasil Belajar IPS. Journal of Drug Issues, Vol. 2, 2252-9047.

Windura, Sutanto. 2008. MIND MAP Langkah Demi Langkah. Jakarta: PT Elex Media Komputindo Kelompok Gramedia. 